\title{
L (+)-lactic acid production by pellet-form Rhizopus oryzae NRRL 395 on biodiesel crude glycerol
}

\author{
Dan C Vodnar', Francisc V Dulf², Oana L Pop ${ }^{1}$ and Carmen Socaciu ${ }^{1 *}$
}

\begin{abstract}
Background: Given its availability and low price, glycerol derived from biodiesel industry has become an ideal feedstock for the production of fuels and chemicals. A solution to reduce the negative environmental problems and the cost of biodiesel is to use crude glycerol as carbon source for microbial growth media in order to produce valuable organic chemicals. In the present paper, crude glycerol was used as carbon substrate for production of $L(+)$-lactic acid using pelletized fungus R. oryzae NRRL 395 on batch fermentation. More, the experiments were conducted on media supplemented with inorganic nutrients and lucerne green juice.

Results: Crude and pure glycerols were first used to produce the highest biomass yield of R. oryzae NRRL 395. An enhanced lactic acid production then followed up using fed-batch fermentation with crude glycerol, inorganic nutrients and lucerne green juice. The optimal crude glycerol concentration for cultivating $R$. oryzae NRRL 395 was $75 \mathrm{~g} \mathrm{I}^{-1}$, which resulted in a fungal biomass yield of $0.72 \mathrm{~g} \mathrm{~g}^{-1}$ in trial without lucerne green juice addition and $0.83 \mathrm{~g} \mathrm{~g}^{-1}$ in trial with lucerne green juice. The glycerol consumption rate was $1.04 \mathrm{gl}^{-1} \mathrm{~h}^{-1}$ after $48 \mathrm{~h}$ in trial with crude glycerol $75 \mathrm{~g} \mathrm{l}^{-1}$ while in trial with crude glycerol $10 \mathrm{~g} \mathrm{l}^{-1}$ the lowest rate of $0.12 \mathrm{~g} \mathrm{l}^{-1} \mathrm{~h}^{-1}$ was registered. The highest $\mathrm{L}(+)$-lactic acid yield $\left(3.72 \mathrm{~g} \mathrm{~g}^{-1}\right)$ was obtained at the crude glycerol concentration of $75 \mathrm{~g} \mathrm{l}^{-1}$ and LGJ $25 \mathrm{~g} \mathrm{l}^{-1}$, and the concentration of lactic acid was approximately $48 \mathrm{~g} \mathrm{l}^{-1}$.

Conclusions: This work introduced sustainable opportunities for $L(+)$-lactic acid production via $R$. oryzae NRRL 395 fermentation on biodiesel crude glycerol media. The results showed good fungal growth on crude glycerol at $75 \mathrm{~g} \mathrm{I}^{-1}$ concentration with lucerne green juice supplementation of $25 \mathrm{~g} \mathrm{I}^{-1}$. Lucerne green juice provided a good source of nutrients for crude glycerol fermentation, without needs for supplementation with inorganic nutrients. Crude glycerol and lucerne green juice ratio influence the $L(+)$-lactic acid production, increasing the lactate productivity with the concentration of crude glycerol.
\end{abstract}

\section{Background}

Energy fuels for world consume are mainly derived for finite and declining reserves of fossil hydrocarbons [1]. Now, there is a global dependency on fossil hydrocarbons, which will not be environmentally and economically sustainable in the long term [1]. Nowadays, having the authority's pessimistic prospects for the future, regarding the absolute dependency on fossil fuels, the political and economical policies are to stimulate the development

\footnotetext{
* Correspondence: socaciucarmen@gmail.com

'Food Science and Technology Department, Unit of Chemistry and Biochemistry, University of Agricultural Sciences and Veterinary Medicine, 3-5 Mănăştur str, Cluj-Napoca 400372, România

Full list of author information is available at the end of the article
}

of sustainable alternatives to fossil fuels. Biodiesel, represent an alternative for the substitution of fossil fuels, which is the most common biofuel in Europe [2]. Similar to the petroleum industry, biodiesel industry generate unwanted by-products [1]. Biodiesel production generate huge amount of crude glycerol- one part of glycerol is produced at every ten parts of biodiesel [3] and has a negative influence on the biodiesel price. The glycerine phase from biodiesel industry causing the environmental problems regarding to the management of this byproduct. A solution to reduce the negative environmental problems and the cost of biodiesel is to use crude glycerol as carbon source for microbial growth media in order to produce valuable organic chemicals $[4,5]$.

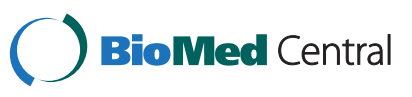


Lactic acid (lactate) and its derivates have many applications in the food, pharmaceutical, and polymer industries [6]. Its most promising application is in being used as a major raw material for the production of polylactic acid (PLA) [7]. In this context, lactic acid can be produced via biological route having the advantage of being able to produce optically pure lactic acid, while chemical route produce racemic mixture with the requirements of high temperature and pressure $[8,9]$.

Lactic acid from biological sources can be produced by both bacteria and fungi fermentation [10]. Production of $\mathrm{L}(+)$-lactic acid via fermentative route has increased in the last decade [7]. For the industrial production of $\mathrm{L}$ $(+)$-lactic acid, it is necessary to provide cheap carbon sources, and to obtain the optimal conditions of fermentation with higher yields and production rates [11]. Generally, bacterial fermentation has a higher yield [12]. Apart from the large group of bacteria, filamentous fungi, especially $R$. oryzae have been proving a good lactic acid producer. $R$. oryzae NRRL 395 can utilize crude glycerol as carbon source, and unlike its competitors of lactic acid producing bacteria, tolerate high impurities, has lower nutrition requirements which reduce the fermentation cost and simplifies downstream product separation $[13,14]$ it is more tolerant to a low $\mathrm{pH}$ environment and the fungal biomass is easy to separate from broth [10].

In the lactic acid production by $R$. oryzae NRRL 395, a considerable amount of chitin is produced [10], which limited the mass transfer of oxygen and nutrients onto the fungus and the release of the organic acid media. Growing fungi in pellet form can reduce these problems.

The aim of the current investigation was to further assess the potentialities of valorization of crude glycerol by pelletized $R$. oryzae NRRL 395, in order to produce $\mathrm{L}(+)$-lactic acid in media supplemented with laboratory nutrients or with lucerne green juice. The pelletized fermentation hold great promise as potential bioconversion route of low-value glycerol streams to a higher-value product like lactic acid.

\section{Results and discussion}

\section{R. oryzae NRRL 395 biomass production}

$R$. oryzae NRRL 395 was successfully cultivated on various biofuel residues, but the extremely high organic content of the crude glycerol was a major concern prior to start this work. Thus, the first study was conducted to evaluate the possibility of $R$. oryzae NRRL 395 to use the crude glycerol as sole carbon source. Nutrient supplemented media containing different carbon sources $30 \mathrm{~g} \mathrm{l}^{-1}$ including, pure glycerol and crude glycerol were selected. The initial organic matters (COD) were different in the substrates. The fungal biomass yield was used to evaluate the feasibility of $R$. oryzae NRRL 395 cultivation on these media. A statistical analysis showed significant differences between the specific fungal biomass yields on crude glycerol and pure glycerol samples at 95\% confidence (Figure 1). The highest specific biomass yield of $0.65 \pm 0.02 \mathrm{~g}$ biomass increase/g initial biomass $\cdot g$ COD $_{\text {removed }}$ ) was obtained on crude glycerol samples. This demonstrated that $R$. oryzae NRRL 395 was able to use crude glycerol as carbon source. These results were in agreement with those reported by Nitayavardhana et al. [15], in which $R$. microsporus var. oligosporus showed a specific biomass yield of $0.64 \pm 0.06 \mathrm{~g}$ on crude glycerol. More, the work reported insignificant differences between fungal biomass yields on media with yeast extract and crude glycerol.

As shown in Figure 2, the optimal crude glycerol concentration for cultivating $R$. oryzae NRRL 395 was $75 \mathrm{~g} \mathrm{l}^{-1}$, which resulted in a fungal biomass yield of $0.72 \mathrm{~g} \mathrm{~g}^{-1}$ in trial without LGJ addition and $0.83 \mathrm{~g} \mathrm{~g}^{-1}$ in trial with LGJ. With respect to the control (CG $100 \mathrm{~g} \mathrm{l}^{-1}$, without nutrient supplementation), at the optimal glycerol concentration (75 $\mathrm{g} \mathrm{l}^{-1}$ ) and $\mathrm{pH} \mathrm{5}$, an improvement in fungal biomass yield was observed with $0.2 \mathrm{~g}$ biomass when crude glycerol samples were supplemented with inorganic nutrients. These results were in agreement whit those reported by Nitayavardhana and Khanal, [16] which demonstrated over $200 \%$ increase in fungal biomass yield in vinasse media supplemented with nitrogen and phosphorus. Generally, the fungal biomass was lower in crude glycerol media supplemented with nutrients than in vinasse. However, nutrient supplements had a lower solubility on crude glycerol, thus led to a slower fungal growth and the use of low-cost nutrient-rich solution will overcome this problem [16].

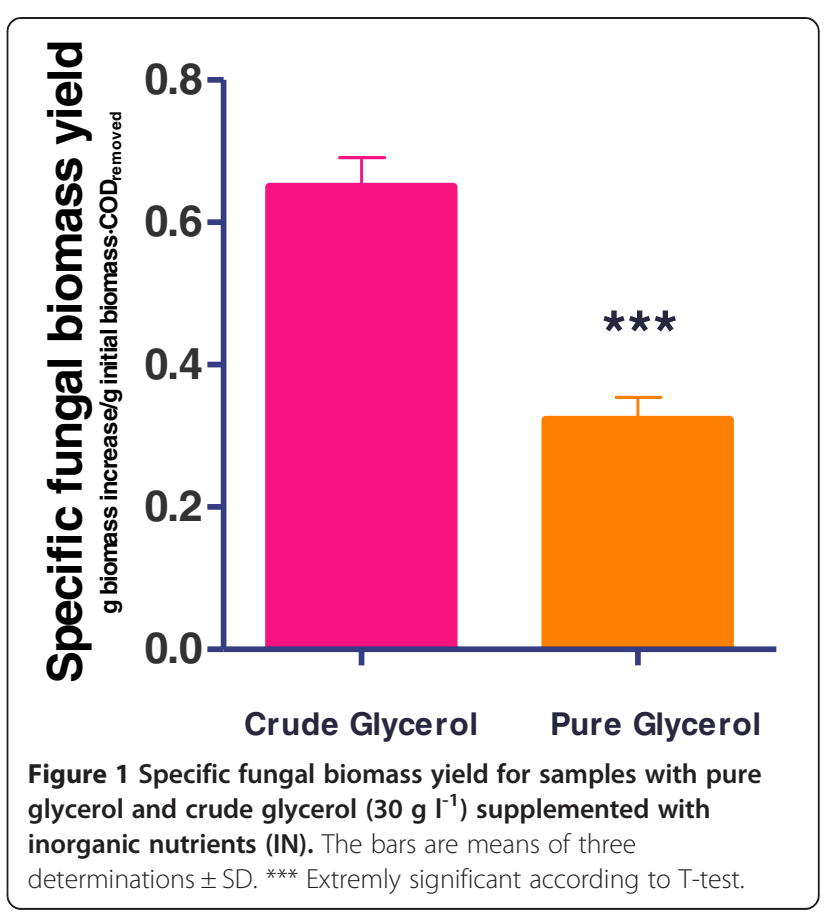




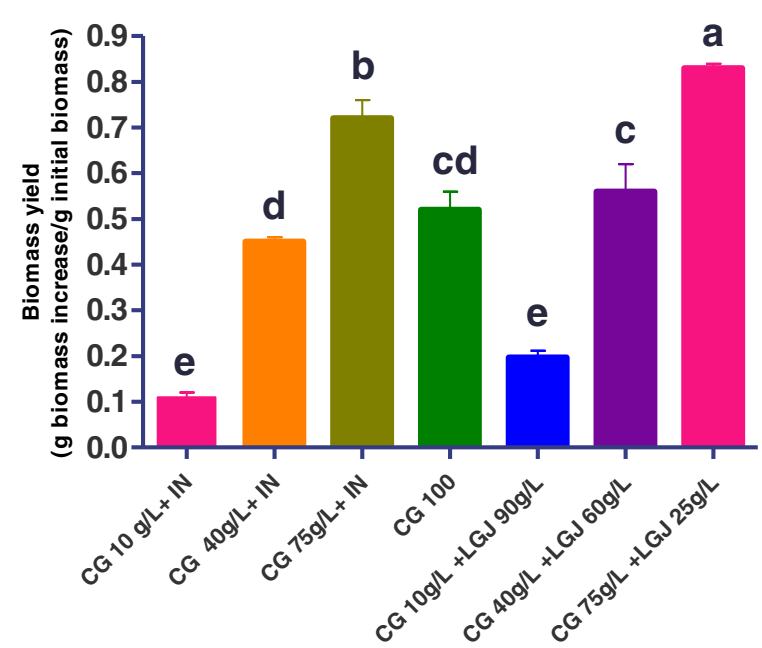

Figure $2 R$. oryzae NRRL 395 biomass yield (g biomass increase/ $\mathrm{g}$ initial biomass) on media containing different ratio of crude glycerol (CG) $\left(10,40,75,100 \mathrm{~g} \mathrm{l}^{-1}\right)$ supplemented with inorganic nutrients (IN) or with lucerne green juice (LGJ 90, 60, $\left.25 \mathbf{g ~ l}^{-1}\right)$. Means $(n=3) \pm S D$. Means with different letter are significantly different $(p<0.05)$.

Another study shows that Lucerne green juice can be use as inexpensive nutrient in lactic acid fermentation [17]. The extracted juice was successfully used as substitute for expensive nutrients for cultivating Lactobacillus paracasei 168 . The study noticed that partial substitution of expensive media components was possible by using lucerne green juice. This finding suggested that lucerne green juice constituted a nutrient supplement for crude glycerol fermentation, substituting the laboratory expensive nutrients used for this kind of fermentations. The lucerne green juice characteristics are summarized in Table 1. It is interesting to note that fungal growth in samples with crude glycerol $10 \mathrm{~g} \mathrm{l}^{-1}$ and $90 \mathrm{~g} \mathrm{l}^{-1} \mathrm{LGJ}$ was not significantly different compared with crude glycerol $10 \mathrm{~g} \mathrm{l}^{-1}$ supplemented with laboratory inorganic nutrients. As shown in Figure 2, a significant fungal biomass yield was observed in crude glycerol supplemented with lucerne green juice LGJ $60 \mathrm{~g} \mathrm{l}^{-1}$ (0.83 $\mathrm{g}$ biomass) and LGJ $25 \mathrm{~g} \mathrm{l}^{-1}$ (0.52 $\mathrm{g}$ biomass). This supports the potential of utilizing a low-cost lucerne green juice as a source of nutrients to enhance the growth of $R$. oryzae NRRL 395.

\section{Kinetics study of lactic acid production in bioreactor Lactic acid production by $R$. oryzae NRRL 395 on glucose substrate}

First, the capacity of $R$. oryzae NRRL 395 for sugar utilization was investigated on glucose as model media. The observation of $R$. oryzae NRRL 395 in consuming glucose and producing $\mathrm{L}(+)$-lactic acid was presented in Figure 3.

The initial concentration of glucose was $101 \mathrm{~g} \mathrm{l}^{-1}$. During the first day of growth, the $R$. oryzae NRRL 395 was
Table 1 Characteristics of lucerne green juice

\begin{tabular}{ll}
\hline Parameters & Values* \\
\hline $\mathrm{pH}$ & $5.98 \pm 0.1$ \\
Sugar $[\mathrm{g} / \mathrm{L}]$ & $16.8 \pm 0.15$ \\
$\mathrm{~N}_{\text {tot }}[\mathrm{g} / \mathrm{L}]$ & $4.5 \pm 0.11$ \\
$\mathrm{P}_{\text {tot }}[\mathrm{g} / \mathrm{L}]$ & $3.47 \pm 0.11$ \\
$\mathrm{DM}[\%]$ & $6.12 \pm 0.19$ \\
$\mathrm{NO}_{2}^{-}[\mathrm{mg} / \mathrm{L}]$ & $15.65 \pm 1.62$ \\
$\mathrm{NO}_{3}^{-}[\mathrm{mg} / \mathrm{L}]$ & $7.50 \pm 0.85$ \\
$\mathrm{Cl}^{-}[\mathrm{mg} / \mathrm{L}]$ & $1560 \pm 64$ \\
$\mathrm{SO}_{4}^{2-}[\mathrm{mg} / \mathrm{L}]$ & $596 \pm 36$ \\
$\mathrm{PO}_{4}^{3-}[\mathrm{mg} / \mathrm{L}]$ & $556.3 \pm 24.16$ \\
$\mathrm{Na}^{+}[\mathrm{mg} / \mathrm{L}]$ & $81.7 \pm 1.29$ \\
$\mathrm{~K}^{+}[\mathrm{mg} / \mathrm{L}]$ & $4968.5 \pm 37.27$ \\
$\mathrm{Mg}^{2+}[\mathrm{mg} / \mathrm{L}]$ & $437.6 \pm 16.2$ \\
$\mathrm{Ca}^{2+}[\mathrm{mg} / \mathrm{L}]$ & $1289 \pm 11.3$ \\
\hline
\end{tabular}

${ }^{*}$ All analysis are based on $\mathrm{n}$ (sample size) $=3$.

adapted itself to the media conditions without showing substantial changes in concentrations of either glucose or L (+)-lactic acid in the culture medium. In the next 2 days, $R$. oryzae NRRL 395 achieved a maximal yield of L (+)-lactic acid after 72 hours of fermentation, indicated by the major consumption of nutrients during this period. In the next 3 days, there was almost no additional L (+)-lactic acid produced (the level remained constant around $59 \mathrm{~g} \mathrm{l}^{-1}$ ). The glucose consumption decreased sharply from 90.5 to $27 \mathrm{~g} \mathrm{l}^{-1}$ after $48 \mathrm{~h}$ and all the glucose was largely used up after $72 \mathrm{~h}$. For this experiment setup, 3 days of incubation were sufficient for the system to reach the stage highest concentration (58.41 $\mathrm{g} \mathrm{l}^{-1}$ ) of $\mathrm{L}(+)$-lactic acid. These results were in agreement to those reported by Yao et al. [18], in which the final lactic acid concentration of $52 \mathrm{~g} \mathrm{l}^{-1}$ was achieved after $72 \mathrm{~h}$ of fermentation.

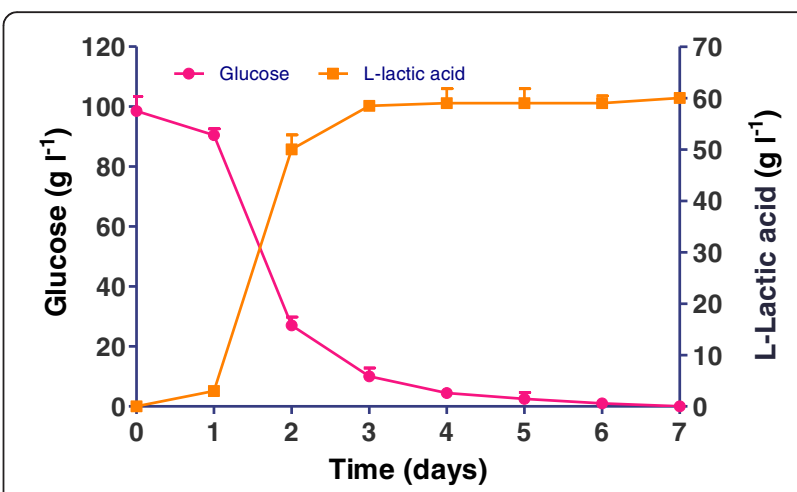

Figure 3 Substrate consumption and product yield curves of $R$. oryzae NRRL 395 during the fermentation conditions on media with glucose $\left(101 \mathrm{~g} \mathrm{l}^{-1}\right)$. The bars are means of

three determinations \pm SD. 
Lactic acid production by $R$. oryzae NRRL 395 on crude glycerol supplemented with inorganic nutrients

Figure 4 demonstrated the trends of glycerol consumption and the $\mathrm{L}(+)$-lactic acid formulation in media with crude glycerol (CG), supplemented with inorganic nutrients. $R$. oryzae NRRL 395 in the culture media with crude glycerol $10 \mathrm{~g} \mathrm{l}^{-1}$ consumed $6.1 \mathrm{~g} \mathrm{l}^{-1}$ glycerol and produced $1.75 \mathrm{~g} \mathrm{l}^{-1} \mathrm{~L}(+)$-lactic acid, showed a lactate yield of $0.34 \mathrm{~g} \mathrm{~g}^{-1}$ (Figure 5) and a productivity of $0.09 \mathrm{~g} \mathrm{l}^{-1} \mathrm{~h}^{-1}$ (Figure 5). Increasing the crude glycerol concentration in the media was considered a possibility to reach higher lactic acid accumulation at the end of fermentations. The highest concentration of glycerol (61.5 $\mathrm{g} \mathrm{l}^{-1}$ ) used by $R$. oryzae NRRL 395 was in fermentation trial with $75 \mathrm{~g} \mathrm{l}^{-1}$ addition of crude glycerol. In this case the lactate yield (Figure 5) and productivity (Figure 6) was $1.64 \mathrm{~g} \mathrm{~g}^{-1}$ and $0.73 \mathrm{~g} \mathrm{l}^{-1} \mathrm{~h}^{-1}$ respectively, after 48 hours, but in a longer fermentation time (168 h) the final lactate yield was $2.31 \mathrm{~g} \mathrm{~g}^{-1}$. In trial with $40 \mathrm{~g} \mathrm{l}^{-1}$ crude glycerol, the lactate yield was $1.59 \mathrm{~g} \mathrm{~g}^{-1}$ producing $13.3 \mathrm{~g} \mathrm{l}^{-1}$ lactic acid after 7 days of fermentation. The glycerol consumption rate was $1.04 \mathrm{~g} \mathrm{l}^{-1} \mathrm{~h}^{-1}$ after $48 \mathrm{~h}$ in trial with crude glycerol $75 \mathrm{~g} \mathrm{l}^{-1}$ while in trial with crude glycerol $10 \mathrm{~g} \mathrm{l}^{-1}$ the lowest rate of $0.12 \mathrm{~g} \mathrm{l}^{-1} \mathrm{~h}^{-1}$ was registered. Based on this data, was apparent that crude glycerol and inorganic nutrient supplements represented a good source for $R$. oryzae NRRL 395 growth and lactic acid production. There are many factors that could influence the growth of $R$. oryzae NRRL 395 such as: medium nutrients, $\mathrm{pH}$, agitation, aeration, medium viscosity and inoculum size [19-21]. Some strains such as Rhizopus.sp. requires strong agitation to form pellets, while others strains needs high $\mathrm{pH}$ [22]. Vially et al. [23] reported no lactate production on glycerol or lactose when $R$. oryzae NRRL 395 UMIP 4.77 was used at a stirring rate of $200 \mathrm{rpm}$. In contrast, Abe et al. [24] founded that R. oryzae NRRL 395 grew vigorously on glycerol but poorly on sucrose and maltose.

\section{Lactic acid production by $R$. oryzae NRRL 395 on crude glycerol supplemented with lucerne green juice}

Stirred -tank bioreactor experiments showed the $R$. oryzae NRRL 395 capacities to grow and produce L (+)-lactic acid on crude glycerol media supplemented with lucerne green juice. As shown in Figure 7 and Figure 8, the highest L (+)-lactic acid yield (3.72 $\left.\mathrm{g} \mathrm{g}^{-1}\right)$ was obtained at the crude glycerol concentration of $75 \mathrm{~g} \mathrm{l}^{-1}$ and LGJ $25 \mathrm{~g} \mathrm{l}^{-1}$, and the concentration of lactic acid was approximately $48 \mathrm{~g} \mathrm{l}^{-1}$. When the LGJ $90 \mathrm{~g} \mathrm{l}^{-1}$ was used, the consumption rate (Figure 8) of glycerol registered after 48 hours of fermentation was $0.12 \mathrm{~g} \mathrm{l}^{-1} \mathrm{~h}^{-1}$ while in trials with $60 \mathrm{~g} \mathrm{l}^{-1}$ and $25 \mathrm{~g} \mathrm{l}^{-1}$ LGJ the consumption rate was $0.51 \mathrm{~g} \mathrm{l}^{-1} \mathrm{~h}^{-1}$ and $1.2 \mathrm{~g} \mathrm{l}^{-1} \mathrm{~h}^{-1}$, respectively. In comparison with glucose $\left(0.58 \mathrm{~g} \mathrm{~g}^{-1}\right)$ (Figure 3$)$ the lactic acid yield was higher in all trials which used LGJ and less in trial with crude glycerol $10 \mathrm{~g} \mathrm{l}^{-1}$ supplemented with inorganic nutrients $\left(0.34 \mathrm{~g} \mathrm{~g}^{-1}\right)$. Generally, the profile in bioreactor fermentation could be divided into two parts at the time point of $48 \mathrm{~h}$ (Figure 7). Prior to $48 \mathrm{~h}, 46.75 \mathrm{~g} \mathrm{l}^{-1} \mathrm{~L}(+)$-lactic acid was produced in trial with $25 \mathrm{~g} \mathrm{l}^{-1}$ LGJ addition, with a productivity of $0.93 \mathrm{~g} \mathrm{l}^{-1} \mathrm{~h}^{-1}$ which was higher than the rest of the trials. From $48 \mathrm{~h}$ to $168 \mathrm{~h}, \mathrm{~L}(+)$-lactic acid concentration reached at a value higher than $47.1 \mathrm{~g} \mathrm{l}^{-1}$. At the end of the fermentation $48.1 \mathrm{~g} \mathrm{l}^{-1} \mathrm{~L}(+)$-lactic acid was obtained. The pellet
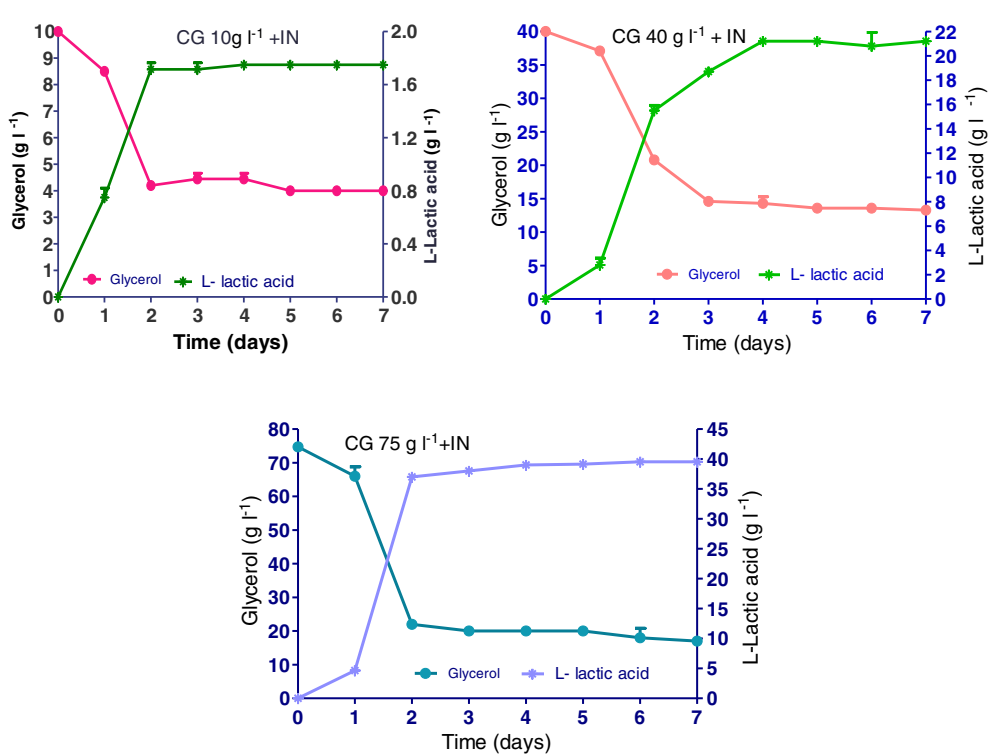

Figure $4 \mathrm{~L}(+)$-lactic acid production and glycerol consumption obtained in trials with crude glycerol (CG) $\left(10,40\right.$, and $\left.75 \mathrm{~g} \mathrm{I}^{-1}\right)$ supplemented with inorganic nutrients. The bars are means of three determinations $\pm S D$. 

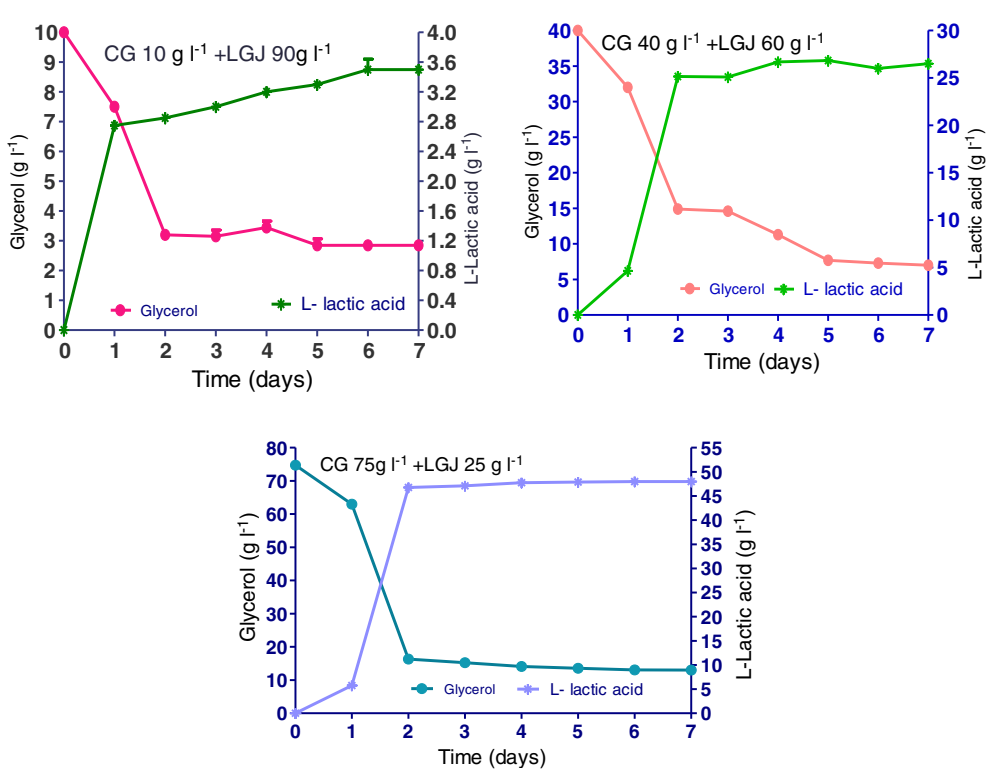

Figure $5 \mathrm{~L}(+)$-lactic acid yield ( $\mathrm{g} \mathrm{L}(+)$-lactic acid/g glycerol) during $R$. oryzae NRRL 395 fermentation in media containing different ratio of crude glycerol (CG) $\left(10,40\right.$, and $\left.75 \mathrm{~g} \mathrm{I}^{-1}\right)$ supplemented with inorganic nutrients (IN) or with lucerne green juice (LGJ) $(90,60$, and $25 \mathrm{~g} \mathrm{l}^{-1}$ ). The error bars in the figure indicate the standard deviations of three parallel replicates \pm SD.

formation observed in these trials might be attributed to the nitrogen and phosphorus content of lucerne green juice that increased the viscosity of culture medium and influenced the $R$. oryzae NRRL 395 growth. More, the potassium content and protein content of lucerne green juice might increase the growth rate of $R$ oryzae in the culture conditions studied. Because of low price and availability, lucerne green juice was a possible feedstock for lactate production. As the increasing interest in producing biotechnological products

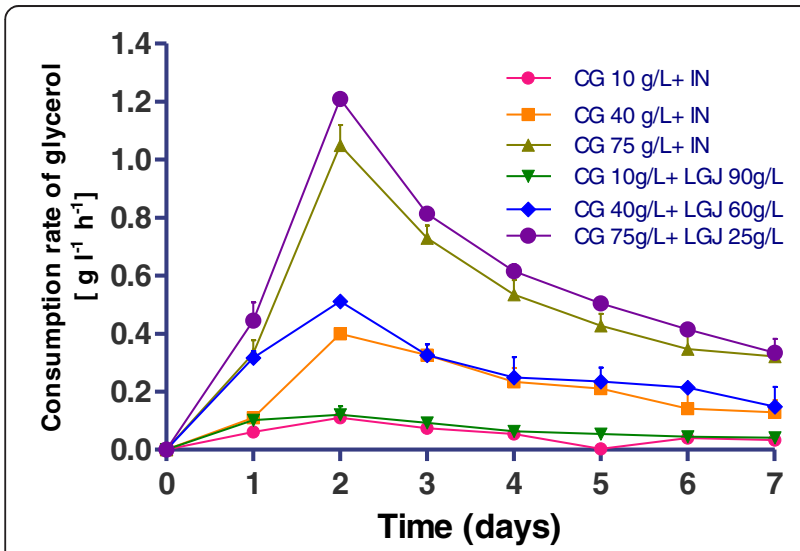

Figure $6 \mathrm{~L}(+)$-lactic acid productivity [concentration of $\mathrm{L}$ (+)-lactic acid (in $\mathrm{g} \mathrm{I}^{-1}$ ) / fermentation time (in h)] during $R$. oryzae NRRL 395 fermentation in media containing different ration of crude glycerol (CG) $\left(10,40\right.$, and $\left.75 \mathrm{~g} \mathrm{l}^{-1}\right)$ supplemented with inorganic nutrients (IN) or with lucerne

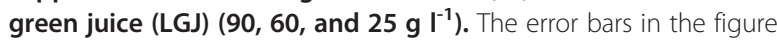
indicate the standard deviations of three parallel replicates \pm SD. from low-cost and renewable biomass, the production of lactic acid from various materials has gained attention recently. Fungal species and lactic acid bacteria (LAB) have been investigated for production of lactic acid. Different yields of $\mathrm{L}(+)$-lactic acid had been reported during fermentation of crude glycerol by LAB strains $\left(0.23-0.71 \mathrm{~g} \mathrm{~g}^{-1}\right)$ [25] or by fungi $\left(0.25-0.86 \mathrm{~g} \mathrm{~g}^{-1}\right)$ [23].

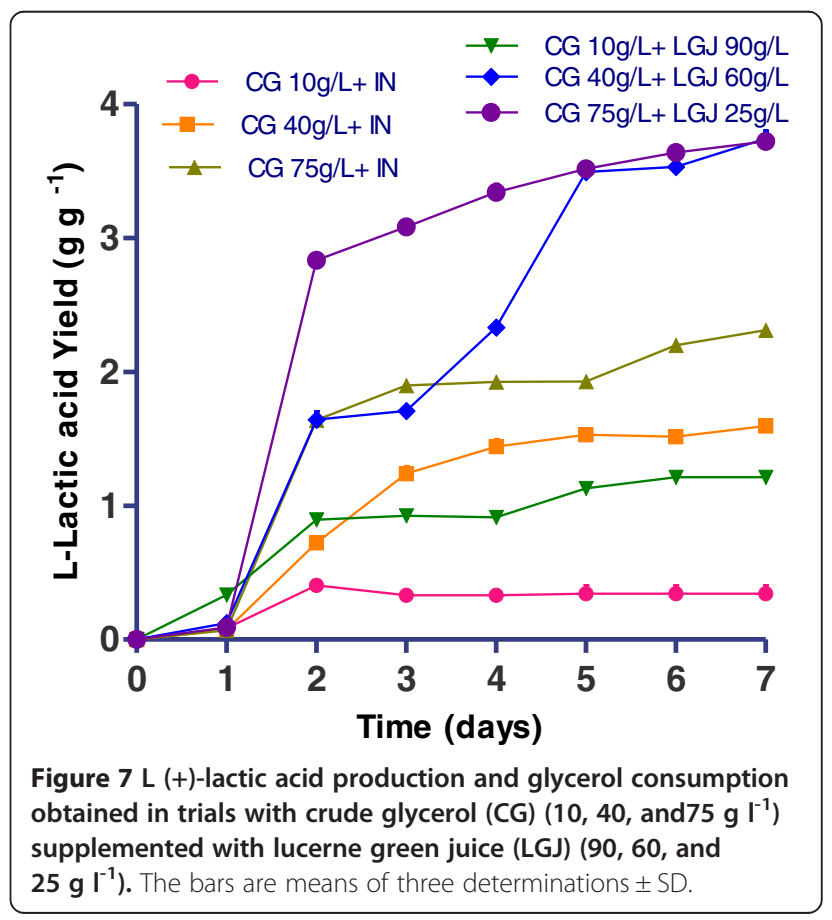




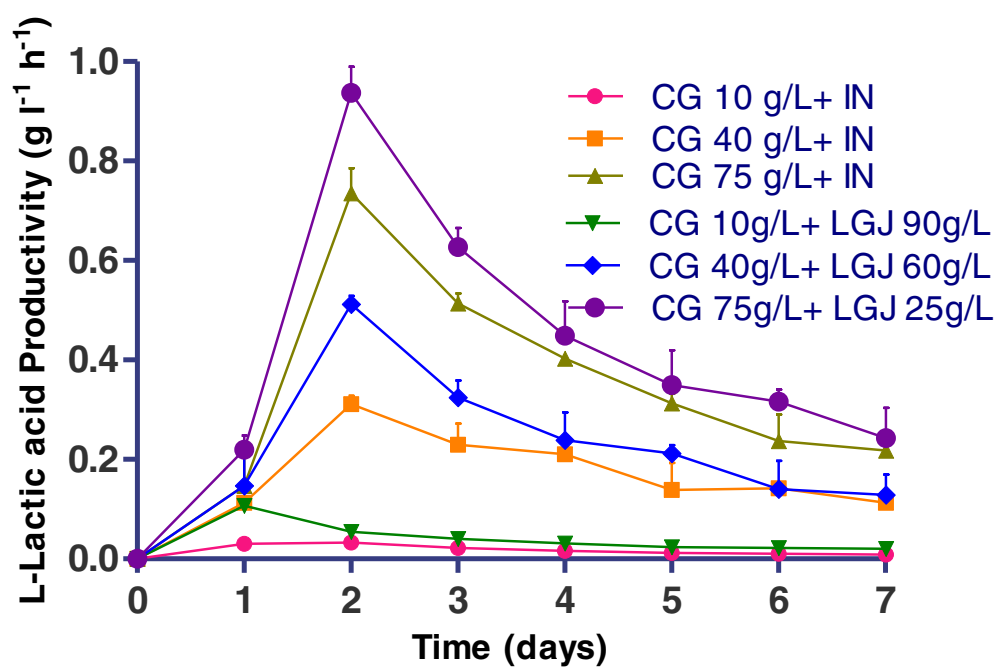

Figure 8 Consumption rate of glycerol [initial concentration of glycerol $\left(\mathrm{g} \mathrm{l}^{-1}\right)$ - residual concentration of glycerol $\left.\left(\mathrm{g} \mathrm{l}^{-1}\right)\right] /$ fermentation time [in h], during $R$. oryzae NRRL 395 fermentation in media containing crude glycerol (CG) $\left(10,40\right.$, and $\left.75 \mathrm{~g} \mathrm{l}^{-1}\right)$ supplemented with inorganic nutrients (IN)

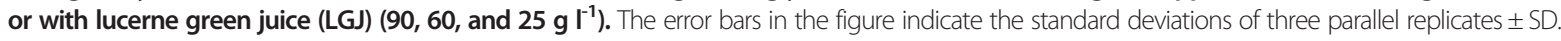

\section{FTIR characterization}

FTIR spectroscopy was expected to be especially valuable in analyzing the phase structure and the product formulation during pelletized fungal fermentation. The infrared spectra of lactic acid, crude glycerol and the sample at the end of the fermentation process from trial with crude glycerol $75 \mathrm{~g} \mathrm{l}^{-1}$ supplemented with inorganic nutrients were showed in Figure 9. The functional group of glycerol, including O-H stretching at $3312 \mathrm{~cm}^{-1}, \mathrm{C}-\mathrm{H}$ stretching at $2983,2935,2883 \mathrm{~cm}^{-1}, \mathrm{C}-\mathrm{O}$ stretching from $1100 \mathrm{~cm}^{-1}$ as primary alcohol to $1400 \mathrm{~cm}^{-1}$ represented the secondary alcohol, $\mathrm{C}-\mathrm{C}$ and $\mathrm{C}-\mathrm{O}$ stretching from 995 to $1050 \mathrm{~cm}^{-1}$ [26]. Specific peak for lactic acid was located at $1112 \mathrm{~cm}^{-1}$ [27]. To study the lactic acid formulation, we followed the band corresponding to lactic acid, which showed changes in the spectra during fermentation processes. These signals validated the HPLC investigations regarding the concentration of lactic acid.

\section{Conclusions}

This work introduced sustainable opportunities for $\mathrm{L}$ (+)-lactic acid production via R. oryzae NRRL 395 fermentation on biodiesel crude glycerol media. The results showed good fungal growth on crude glycerol at $75 \mathrm{~g} \mathrm{l}^{-1}$ concentration with lucerne green juice supplementation. Lucerne green juice provided a good source of nutrients for crude glycerol fermentation, without required for supplementation with inorganic nutrients. Crude glycerol and lucerne green juice ratio influenced the L (+)-lactic acid production, increased the lactate productivity once with the concentration of crude glycerol. Further research on scaling -up the process and monitorization by FTIR spectroscopy of L (+)-lactic acid production on bioreactor is required.

\section{Methods}

Glycerol

Crude glycerol was derived from the transesterification reaction of soybean oil and ethanol catalyzed by $\mathrm{NaOH}$. The $\mathrm{pH}$ of glycerine phase was corrected with $\mathrm{H}_{2} \mathrm{SO}_{4}(1 \mathrm{~N})$ to eliminate the free alkalinity. It was then subject to heating (up to $120^{\circ} \mathrm{C}$ for approximatively $1 \mathrm{~h}$ ) under agitation to eliminate ethanol. The sulphate resulting from the neutralization was separated by decantation during $24 \mathrm{~h}$.

\section{Lucerne green juice}

From the pressing procedure, $2.13 \mathrm{~kg}$ green juice and $2.87 \mathrm{~kg}$ press cake were obtained from $5 \mathrm{~kg}$ chopped Lucerne. The juice was drawn off into plastic containers stored until required, at temperature of $-18^{\circ} \mathrm{C}$. The important characteristics of lucerne green juice are summarised in Table 1.

\section{R. oryzae NRRL 395 cultivation}

The fungus $R$. oryzae NRRL 395 was obtained from USAMV microorganism bank. The fungus was first grown on potato-dextrose agar (PDA) (Sifin) slants at $30^{\circ} \mathrm{C}$ for 7 days. For experiments, the fungal spores in the slant were resuspended in sterilized water maintaining at $3^{\circ} \mathrm{C}$. In terms of achieving pellet form, the spore solution was inoculated in a $125 \mathrm{ml}$ Erlenmeyer flask, containing $50 \mathrm{ml}$ of seed medium with a spore concentration of $1 \mathrm{x}$ $10^{7}$ spore $/ \mathrm{ml}$, and cultured at $27^{\circ} \mathrm{C}$ on shaker (Heidolph Unimax 1100) set at $180 \mathrm{rot} / \mathrm{min}$ for 24 hours. The cultured temperature was set at $27^{\circ} \mathrm{C}$. The pellet was decanted by centrifugation at $15000 \mathrm{rpm}$ for $15 \mathrm{~min}$ and used for the following experiments. 


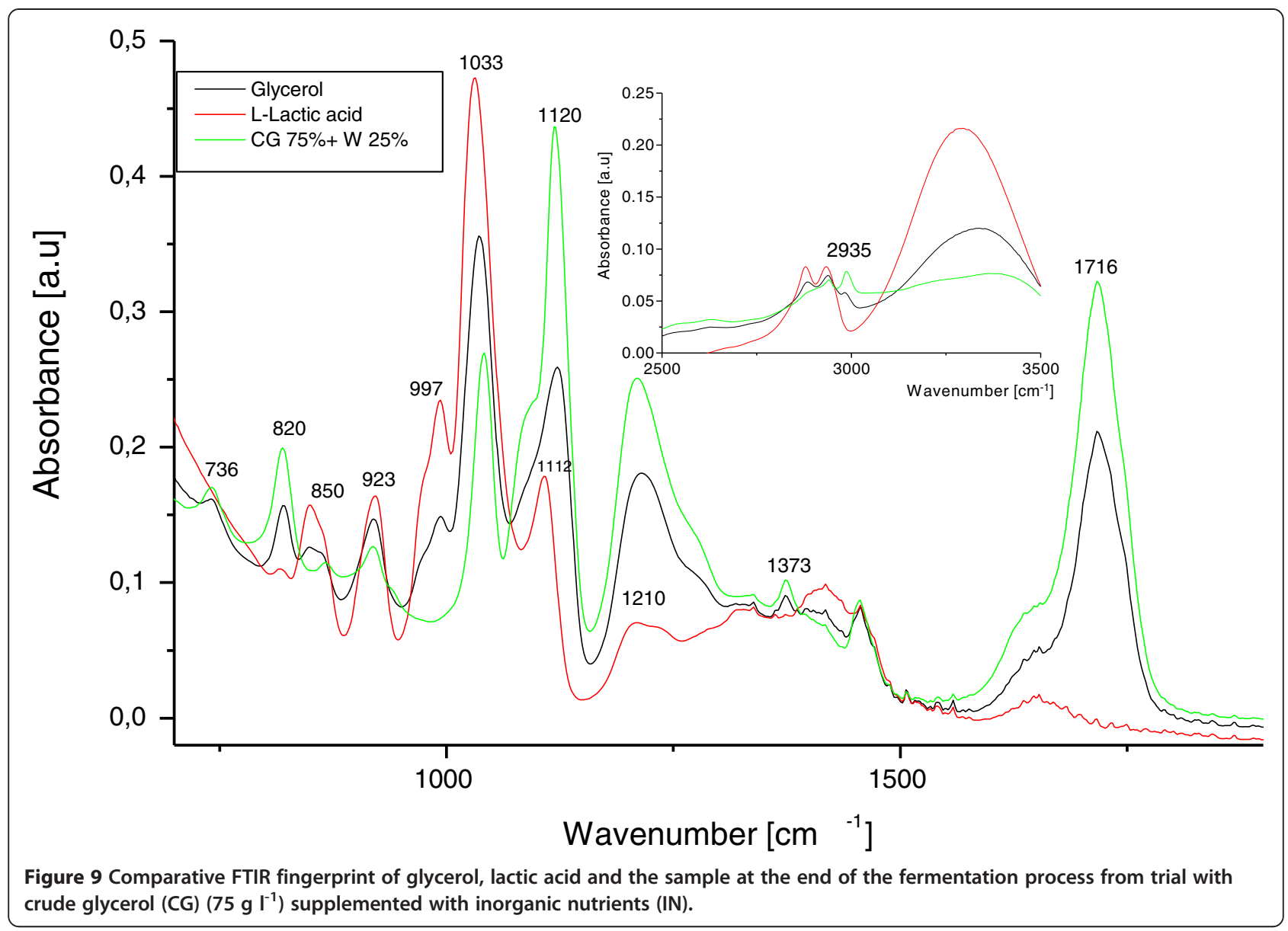

Kinetic study of lactic acid production in bioreactor

The kinetic study was performed on media containing $10 \mathrm{~g} \mathrm{l}^{-1}, 40 \mathrm{~g} \mathrm{l}^{-1}, 75 \mathrm{~g} \mathrm{l}^{-1}$ and $100 \mathrm{~g} \mathrm{l}^{-1}$ crude glycerol with tap water and inorganic nutrient supplementation. Media with inorganic nutrient supplementation contained 0.0092\% $\mathrm{CaCl}_{2} \cdot 2 \mathrm{H}_{2} \mathrm{O}, 0.4 \% \mathrm{MgSO}_{4} \cdot 7 \mathrm{H}_{2} \mathrm{O}, 0.6 \% \mathrm{KH}_{2} \mathrm{PO}_{4}$, and $1.6 \%$ $\left(\mathrm{NH}_{4}\right) 2 \mathrm{SO}_{4}$. The second scenario consisted in the substitution of inorganic nutrient supplements with lucerne green juice, thus the fermentation media containing $10 \mathrm{~g} \mathrm{l}^{-1}$, $40 \mathrm{~g} \mathrm{l}^{-1}, 75 \mathrm{~g} \mathrm{l}^{-1}$ crude glycerol with lucerne green juice $90 \mathrm{~g} \mathrm{l}^{-1}, 60 \mathrm{~g} \mathrm{l}^{-1}$, and $25 \mathrm{~g} \mathrm{l}^{-1}$. In all samples the $\mathrm{pH}$ was adjusted to 5.5 with calcium carbonate $\left(35 \mathrm{~g} \mathrm{l}^{-1}\right)$. The bioreactor containing the medium was sterilized in autoclave at $121^{\circ} \mathrm{C}$ for $15 \mathrm{~min}$. Inoculum was transferred to the fermentation media at $1 \times 10^{7} \mathrm{spore} / \mathrm{ml}$. The bioreactor used for the fermentative assays was the Electrolab FERMAC 360 with a vessel volume of $2.9 \mathrm{~L}$, equipped with a digital control unit. The fermentation was carried out at $27^{\circ} \mathrm{C}$ with $360 \mathrm{rpm}$ agitation speed and $1 \mathrm{vvm}$ aeration rate.

\section{Analytical methods}

The lucerne green juice samples were dried to a constant weight at $102^{\circ} \mathrm{C}$ to dry matter (DM102). For total solids analysis, the dried residue was weighed and heated in a crucible for $2 \mathrm{~h}$ at $550^{\circ} \mathrm{C}$ in a preheated furnace. After cooling, the crucible and ash were weighed. The total nitrogen content $\left(\mathrm{N}_{\text {tot }}\right)$ was analyzed using the standard method Kjeldahl. The colorimetric technique was used to measure the total phosphorus with the molybdenum blue method. Anions and cations were determined under the following conditions using the ion chromatograph Agilent 1200 Series HPLC: IonPac AS14 (4 mm) column (anions) and IonPac CS12A ( $4 \mathrm{~mm}$ ) column (cations). The eluent was $3 \mathrm{mM}$ disodium carbonate, $1 \mathrm{mM}$ sodium hydrogen carbonate (anions) and $23 \mathrm{mM}$ sulfuric acid (cations) with a flow rate of $1 \mathrm{~mL} / \mathrm{min}$. The injection volume was $20 \mu \mathrm{L}$. Aliquots of the fermentation liquid were taken every $24 \mathrm{~h}$ to determine L-lactic acid and glycerol concentration. The content of lactic acid and glycerol was determined by HPLC (Dionex) using a Eurokat $\mathrm{H}$ column $(300 \times 8 \mathrm{~mm}, 10 \mathrm{~lm})$ and an differential refractometer RI-71 detector with a detection limit of $0.01 \mathrm{~g} / \mathrm{L}$. The mobile phase was $0.01 \mathrm{NH}_{2} \mathrm{SO}_{4}$ using isocratic elution with a flow rate of $0.9 \mathrm{~mL} / \mathrm{min}$. The chemical oxygen demand (COD) was determined by Standard Methods \#5220 [28].

The yield of L (+)-lactic acid, productivity and the consumption rate of glycerol were calculated as: 
Yield of lactic acid $=\mathrm{gL}(+)$-lactic acid/g glycerol

$L(+)$-lactic acid productivity $=$ concentration of $\mathrm{L}(+)$-lactic acid $\left(\right.$ in $\left.^{-1}\right) /$ fermentation time $($ in $\mathrm{h})$

Consumption rate of glycerol $=$ initial concentration of glycerol $\left(\mathrm{g}^{-1}\right)$ -residual concentration of glycerol $\left(\mathrm{g} \mathrm{l}^{-1}\right) /$ fermentation time (in h)

\section{Biomass yield and specific biomass yield}

The biomass yield was determined following 96 hours of fermentation. The inoculum for trials was fixed at $0.12 \mathrm{~g}$ dry pellet biomass $\mathrm{I}^{-1}$. The collected samples after the fermentation were centrifuged at $4000 \mathrm{rpm}$ for $15 \mathrm{~min}$. The precipitated biomass was washed twice using $4 \mathrm{~N}$ $\mathrm{HCl}$ to remove residual calcium carbonate and the biomass was determined by weighing the mass after drying at $80^{\circ} \mathrm{C}$ overnight.

\section{Biomass yield $=$ g biomass increase $/ \mathrm{g}$ initial biomass}

Specific biomass yield $=$ grams biomass increase/gram initial biomass. COD removed, and was determined in order to compare fungal growth in various samples with different initial organic content.

\section{FTIR characterization of the fermentation processes} FTIR spectra using attenuated total reflectance (ATR) and an internal reflection accessory made of composite zinc selenide $(\mathrm{ZnSe})$ and diamond crystals were obtained on a Schimatzu IR Prestige- 21 spectrometer. Each spectrum was registered from 4000 to $500 \mathrm{~cm}^{-1}$. The FTIR spectra were recorded for all samples in parallel with controls. Three spectra were acquired for each trial variant at room temperature. Each spectrum was composed of an average of 128 separate scans. The measuring time was approximately 9 minutes per sample $(\mathrm{n}=3)$, depending on the number of scans per spectrum. Accordingly, as the average number of scans increased, the measuring time increased.

\section{Statistical analysis}

All experiments were conducted in triplicates and ANOVA and $\mathrm{t}$-tests were employed to determine if there was statistical difference between trials at significance level of $\mathrm{p}<0.05$ using Graph Prism 4.0 (Graph Pad Software Inc., San Diego, CA, USA).

\footnotetext{
Abbreviations

LGJ: Lucerne green juice; COD: Chemical oxygen demand; CG: Crude glycerol; IN: Inorganic nutrients.
}

\section{Competing interests}

The authors declare that they have no competing interests.

\section{Authors' contributions}

CS, FVD, OLP carried out the chemical investigations regarding the Lucerne green juice and glycerol characterization. DV contributed to the fermentation experimental work, measuring the lactic acid and glycerol content and recording the FTIR spectra, and wrote the manuscript. All authors read and approved the final manuscript.

\section{Acknowledgements}

This work has supported by a research grant of University of Agricultural Sciences and Veterinary Medicine, Cluj-Napoca.

\section{Author details}

${ }^{1}$ Food Science and Technology Department, Unit of Chemistry and Biochemistry, University of Agricultural Sciences and Veterinary Medicine, 3-5 Mănăştur str, Cluj-Napoca 400372, România. ${ }^{2}$ Department of Environmental and Plant Protection, University of Agricultural Sciences and Veterinary Medicine, 3-5 Mănăştur str, Cluj-Napoca 400372, România.

Received: 30 July 2013 Accepted: 7 October 2013 Published: 10 October 2013

\section{References}

1. Dobson R, Gray V, Rumbold K: Microbial utilization of crude glycerol for the production of value-added products. J Ind Microbiol Biotechnol 2012, 39:217-226

2. Drozdzynska A, Leja K, Czaczyk K: Biotechnological production of 1,3propanediol from crude glycerol. J Biotechnol Comp Bio Bionanotechnol 2011, 92:92-100.

3. Rossi DM, da Costa JB, de Souza EA, Perelba MCR, Ayub MAZ: Bioconversion of residual glycerol from biodiesel synthesis into 1,3propanediol and ethanol by isolated bacteria from environmental consortia. Renew Energ 2012, 39:223-227.

4. Kosmider A, Drozdzynska A, Blaszka K, Leja K, Czaczyk K: Propionic acid production by Propionibacterium freudenreichii ssp. shermanii using industrial wastes: crude glycerol and whey lactose. Pol J Environ Stud 2010, 19:1249-1253.

5. Yang F, Hanna MA, Sun R: Value-added uses for crude glycerol-a byproduct of biodiesel production. Biotechnol Biofuels 2012, 5:13.

6. Okano K, Tanaka T, Ogino C, Fukuda H, Kondo A: Biotechnological production of enantiomeric pure lactic acid from renewable resources: recent achievements, perspectives, and limits. Appl Microbiol Biotechnol 2010, 85:413-423.

7. Zhao J, Xu L, Wang Y, Zhao X, Wang J, Garza E, Manow R, Zhou S: Homofermentative production of optically pure L-lactic acid from xylose by genetically engineered Escherichia coli B. Microb Cell Fact 2013, 12:57.

8. Vaidya AN, Pandey RA, Mudliar S, Kumar MS, Chakrabarti T, Devotta S: Production and recovery of lactic acid for polylactide -an overview. Crit Rev Environ Sci Technol 2005, 35:429-467.

9. Oh H, Wee YJ, Yun JS, Han SH, Jung SW, Ryu HW: Lactic acid production from agricultural resources as cheap raw materials. Bioresour Technol 2005, 96:1492-1498.

10. Liu Y, Liao W, Chen S: Co-production of lactic acid and chitin using a pelletized filamentous fungus Rhizopus oryzae cultured on cull potatoes and glucose. J Appl Microbiol 2008, 105:1521-1528.

11. Ilmén M, Koivuranta $K$, Ruohonen $L$, Rajgarhia $V$, Suominen $P$, Penttilä M: Production of I-lactic acid by the yeast Candida sonorensis expressing 
heterologous bacterial and fungal lactate dehydrogenases. Microb Cell Fact 2013, 12:53.

12. Litchfield JH: Microbiological production of lactic acid. Adv App/ Microbiol 1996, 42:45-95.

13. Tsao GT, Cao NJ, Du J, Gong CS: Production of multifunctional organic acids from renewable resources. Adv Biochem Eng Biotechnol 1999, 65:243-280

14. Magnuson JK, Lasure LL: Organic acid production by filamentous fungi. In Advances in fungal biotechnology for industry: agriculture and medicine. Edited by Tkacz JS, Lange L. New York: Plenum; 2004:307-384

15. Nitayavardhana S, Khanal SK: Biodisel-derived crude glycerol bioconversion to animal feed: a sustainable option for a biodiesel refinery. Bioresour Technol 2011, 102:5808-5814.

16. Nitayavardhana S, Khanal SK: Innovative biorefinery concept for sugar based ethanol industries: production of protein-rich fungal biomass on vinasse as an aquaculture feed ingredient. Bioresour Technol 2010, 101:9078-9085.

17. Vodnar DC, Venus J, Schneider R, Socaciu C: Lactic acid production by Lactobacillus paracasei 168 in discontinuous fermentation using lucerne green juice as nutrient substitute. Chem Eng Technol 2010, 33:468-474.

18. Yao W, Wu X, Zhu J, Sun B, Miller C: Utilization of protein extract from dairy manure as a nitrogen source by Rhizopus oryzae NRRL-395 for L-lactic acid production. Bioresour Technol 2010, 101:4132-4138.

19. Metz B, Kossen NWF: Growth of molds in form of pellets - literature review. Biotechnol Bioeng 1977, 19:781-799.

20. Papagianni M: Fungal morphology and metabolite production in submerged mycelial processes. Biotechnol Adv 2004, 22:189-259.

21. Znidarsic $P$, Komel $R$, Pavko A: Influence of some environmental factors on Rhizopus nigricans submerged growth in the form of pellets. World J Microbiol Biotechnol 2000, 16:589-593.

22. Liu Y: Co-production of lactic acid and chitin using a pelletized filamentous Rhizopus oryzae culture from cull potatoes. J Appl Microbiol 2008, 105:1521-1528.

23. Vially G, Marchal R, Guilbert N: L (+) Lactate production from carbohydrates and lignocellulosic materials by Rhizopus oryzae UMIP 4.77. World J Microbiol Biotechnol 2010, 26:607-614.

24. Abe A, Sone T, Sujaya IN, Saito K, Oda Y, Asano K, Tomita F: RDNA ITS sequence of R. Oryzae NRRL 395: its application to classification and identification of lactic acid producers. Biosci Biotechnol Biochem 2003, 67:1725-1731

25. Wang L, Zhao B, Liu B, Yu B, Ma C, Su F, Hua D, Li Q, Ma Y, Xu P: Efficient production of L-lactic acid from corncob molasses, a waste by-product in xylitol production, by a newly isolated xylose utilizing bacillus sp strain. Bioresour Technol 2010, 101:7908-7915.

26. Calvino-Casilda V, Mul G, Fernández JF, Rubio-Marcos F, Bañares MA: Monitoring the catalytic synthesis of glycerol carbonate by real-time attenuated total reflection FTIR spectroscopy. Appl Catal A Gen 2011, 409:106-112.

27. Vodnar DC, Pop OL, Socaciu C: Monitoring lactic acid fermentation in media containing dandelion (taraxacum officinale) by FTIR spectroscopy. Not Bot Horti Agrobo 2012, 40:65-68.

28. American Public Health Association/American Water Works Association/ Water Environment Federation (APHA/AWWA/WEF: Standard methods for the examination of water and wastewater. 21st edition. DC, USA: Washington; 2005

doi:10.1186/1475-2859-12-92

Cite this article as: Vodnar et al: L (+)-lactic acid production by pelletform Rhizopus oryzae NRRL 395 on biodiesel crude glycerol. Microbial Cell Factories 2013 12:92.

\section{Submit your next manuscript to BioMed Central and take full advantage of:}

- Convenient online submission

- Thorough peer review

- No space constraints or color figure charges

- Immediate publication on acceptance

- Inclusion in PubMed, CAS, Scopus and Google Scholar

- Research which is freely available for redistribution

Submit your manuscript at www.biomedcentral.com/submit
Biomed Central 